Revista Iberoamericana. Vol. LXIV, Núms. 182-183, Enero-Junio 1998; 81-94

\title{
UMA LITERATURA CENTÁURICA
}

\author{
POR \\ Raúl ANTELo \\ Universidade Federal de Santa Catarina, Brasil
}

\begin{abstract}
Examen d'ensemble: le caractère ambigu de notre monde moderne. - Ce sont les mêmes symptômes qui pourraient être interprétés dans le sens de l'abaissement et de la force. Et les indices de la force, de l'émancipation conquise, au nom d'appréciations sentimentales héréditaires (détritus que nous charrions), pourraient être mal interprétés comme de la faiblesse. En un mot, le sentiment, en tant que sentiment de valeur, n'est pas à la hauteur du temps.

D'une façon générale: le sentiment de valeur est toujours en retard, il exprime des conditions de conservation, de croissance d'une époque bien antérieure: il lutte contre de nouvelles conditions d'existence, d'où il n'est pas sorti et que, nécessairement, il interprète mal: il entrave, il éveille méfiance de ce qui est nouveau ...
\end{abstract}

Nietzsche - La volonté de puissance

Uma das consequências do recuo das identidades, na modernidade tardia, consiste em dissolver os traços característicos do "nacional" em comportamentos específicos, individuais, descrentes da comunicação intersubjetiva ou de processos culturais supranacionais, suscetíveis ambos de elaborarem suas diferenças sobre um fundamento identitário compartilhado. Após uma fase inequivocamente datada (Havana, 1959), a partir da qual ensaiamos construtos homogêneos e unificantes, a tendência atual inclina-se a trabalhar com fluxos e diferenças, de si para si, que não mais definem uma forma constantemente igual a si mesma mas um conjunto variável de relações e interferências entre as diversas formas culturais. É precisamente a constituição histórica dessas diferentes formas de subjetividade, contempladas a partir de um historicismo radical, que hoje parece orientar nossa atenção em direção às multiplicidades subjetivas, ora em sua submissão ou sujeição a outras subjetividades, ora na possibilidade de um conhecimento autêntico de si. Nenhum ensaio de articulação entre escrituras (do Brasil e do resto da América Latina) pode ser insensível a essa reacomodação de forças. 
Esse processo, que marca fundamente certo nietzscheanismo contemporâneo (o de Foucault, por exemplo) é elemento presente já no início do debate sobre a modernidade no Brasil. Com efeito, na segunda série de seus Estudos (1928) Alceu Amoroso Lima resenha um tratado de psiquiatria, Física e caráter (1921), nele destacando a tipologia proposta por Ernst Kretschmer, a dos ciclóides opostos aos esquizóides. Ao passo que a vida dos ciclóides é uma lenta ondulação entre momentos de alegria e de tristeza, a vida dos esquizóides decorre entre extremos de hiperestesia e anestesia, modulada por inúmeras variações. Essa tipologia prefigura certos rumos do próprio modernismo. A antropofagia, ciclóide, propõe a disjunção (isto ou aquilo) ao passo que o ensaio modernista de Alceu, mas também a pós-poesia de Murilo Mendes, podem ilustrar aqueles que "são isto $e$ aquilo. Que conciliam em si coisas inconciliáveis. Que vivem dilacerados entre coisas contraditórias. Ou que se realizam, duramente, asperamente, por um domínio assombroso da vontade sobre o tumulto interior. Ou então quando perdem ou não possuem essa energia férrea da vontade que coordena, que disciplina, que agride as contradições íntimas, deixam-se dominar por uma reclusão irritada, amarga, sombria, que pode levar aos estados catatônicos extremos" (Lima 304). Como em Pascal ou em Nietzsche.

Nietzsche é, de fato, central na concepção de uma esquizossemia moderna. Estudar a gênese de sua trajetória nos fornece não apenas um quadro acabado dos investimentos disciplinários que visando a identidade nacional apelam, em última análise, à equivalência entre racionalidade e modernidade, mas também a lógica de sua reemergência, na exaustão dessas formas, como força reativa do desejo contra si próprio. Afinal o último Deleuze, nessa introdução à vida não-fascista, como queria Foucault, que são o Anti Edipo e Mille plateaux, interpreta o nosso fim de século em termos de esquizofrenia, não mais no arcaico horizonte niilista do primeiro Nietzsche mas como projeto de converter o passivo ou parasita em ativo ou hospedeiro. O esquizo deixa de ser fuga do social, como ainda podia interpretar o católico Tristão de Athayde, e passa a ser busca de uma marginalidade, onde o social emerge por uma série de furos e cortes, que o esgarçam e transpassam, como energia efetivamente transgressora. Em seus derradeiros ensaios, onde novamente se cruzam crítica e clínica, Deleuze dirá:

L'eternel retour est actif et affirmatif; il est l'union de Dionysos et d'Ariane. C'est pour quoi Nietzsche le compare, non seulement à l'oreille circulaire, mais a l'anneau nuptial (...) Le labyrinthe n'est plus le chemin où l'on se perd mais le chemin qui revient. Le labyrinthe n'est plus celui de la connaissance et de la morale, mais celui de la vie et de l'Etre comme vivant (134).

Três são, portanto, as emergências nietzscheanas que me interessa revisitar nestas páginas. Três traduções de Nietzsche. Poder-se-ia dizer, nas trilhas do que Vincent Descombes descreve para o caso francês, que há, na América Latina, três momentos nietzscheanos (97-125). O primeiro é o dos escritores contemporâneos do filósofo, o espírito fim-de-século, decadentista e adandinado; o segundo, o de escritores não conformistas do período entre-guerras e o terceiro, o pensamento 68 . 
Mesmo os primeiros leitores brasileiros de Nietzsche percebiam nele a dificuldade em resgatar uma vontade de verdade.

Sistema? Não tinha essa preocupação. É muito difícil extrair dos seus livros uma intuição geral do mundo, ou uma sintaxe do universo que ele queria sem gravitações e sem obediências. A sua natureza era essencialmente fragmentária e libérrima. Já em 1896, com efeito, João Ribeiro reconhecia que Nietzsche pensava como escrevia, em pequenos cadernos, ensaios e aforismos e, portanto, "não é difícil apanhá-lo em contradição, como o faria uma crítica estreita e mesquinha; o mais certo seria, e é, apanhá-lo em progresso e inconstância (Ribeiro 18).

Veja-se, entretanto, que essa inconformidade à ordem fez com que Nietzsche não gozasse de fortuna entre pensadores e garantisse sua recepção tão somente no campo estético. O baiano Péthion de Villar, cita, pioneiro, o Zarathustra, em 1900, e pouco depois, José Veríssimo o lê, sob ótica artística, como "profundamente artista, unicamente artista, morbidamente artista", preocupado apenas em nos apresentar o mundo como construção ininteligível. Porém, essa atitude desmistificadora, conquanto materialista, porque se interroga, de fato, pelas limitações da vida, logo surge aos olhos de Veríssimo como

plena e desabrida metafísica, que não pode sequer constituir uma dessas utopias com que se tem engambelado a humanidade, pois, menos que nenhuma outra, é sem apoio no raciocínio, nos fatos, nas noções científicas, na experiência: a pura imaginação, a louca da casa, desvairada nos caminhos da filosofia (Veríssimo 409)

Seriam pois os "purosartistas" os que deveriam acusar uma recepção mais sensível do pensamento nietzscheano? Vejamos.

Nessa outra linha de especial artificialismo, abeberado não só em Nietzsche mas também em Oscar Wilde, Godofredo de Alencar, o alter-ego de Paulo Barreto, imaginava que

se por acaso aparecesse no Brasil um Artista, esse homem teria de lutar com o espírito democrático do vulgar que desconhece os valores, confunde os poetas com os amanuenses, julga inutilidade pensar e faz da arte uma burocracia (...) Ora, o homem superior só tem direito à vida se sabe manter sempre viva e imprevista a surpresa do seu ideal. Por isso talvez o teimoso Heráclito dizia que a razão é uma epilepsia (Rio, Crônicas e frases 211).

Em vertente anti-nietzscheana (Veríssimo) ou pró-nietzscheana (João do Rio), ambas as leituras reforçam a tese ... nietzscheana da morte do homem. Veríssimo alude a ela quando nos mostra as ciências como efetivas sobrevivências do humanismo metafísico, reificando o homem, tornando-o objeto de um estudo sério e desprezando, justamente, a "humanidade do homem", donde, podemos concluir, o conceito de homem está esvaziado, senão morto. 
João do Rio, por sua vez, nos mostra o artista, ser fraturado e opaco para si próprio, como substituto do homem exaurido da modernidade. A alternativa seriam os gregos, a seu ver, fundadores de uma ética sem subjetividade, uma ética do indivíduo, fortemente ancorada no vínculo entre prazer e desejo e dissociada de qualquer culpabilidade, ética essa que ainda teria lições para nos dar e refundar, assim, o Esclarecimento. Ocorre, porém, que essa defesa intransigente do artista não raro leva os nietzscheanos brasileiros a uma consequente legitimação do poder, mesmo que manu militari. Adão, "o primeiro herói da energia", "o primeiro super-homem, inicial de Zarathustra", é um César perverso, capaz de todas as qualidades mas também de todas as infâmias, uma pura "energia para além do bem e do mal". Para o bem, com Pinheiro Machado, mártir republicano, como lemos No tempo de Wenceslau (Rio 4352). Para o mal, "com os estudistas sul-americanos", com os quais o povo realiza prova de sua hegemonia mas é, ao mesmo tempo, vítima "de um conto do vigário dos inferiores contra os grandes" (Rio, Crônicas e frases 58). Ainda em Brava gente (1921), outro nietzscheano, Elysio de Carvalho, toma o duelo entre Bento Gonçalves e Onofre Pires para nele ver uma "luta de centauros", confronto fundacional da estirpe nacionalista. Trata-se, como se vê, de vertente extremamente viva, nos anos 30 , em teóricos do autoritarismo brasileiro. Baste citar As fontes da vida no Brasil de Alberto Torres.

Voltemos, contudo, ao argumento de João do Rio. A idéia da razão como epilepsia pode, ainda, ser lida como propedêutica a uma vida emancipada; daí o papel fundamental da arte: mostrar que a cultura é uma ficção auto-sustentada em que existimos, como invenções do vivente, e somos lançados, a partir da paixão dionisíaca, no suportável e no mediado. Sloterdijk argumenta que a própria vida deve sua elevação ao caráter de cultura a essa dialética do suportável e do insuportável, que está na base do processo de substituição. Isto garante conceber uma ética moderna, feita sob medida do possível, "uma ética de aparência necessária, uma ética das suportabilidades, uma ética dos mundos mediadores, uma ética da ecologia da dor e do prazer, uma ética da vida inventiva"(173). Conciliam-se, assim, ética e estética, terapêutica e política. Concebese, assim, o Esclarecimento como um pensamento arrojado na fronteira da dor, que eleva sua voz contra a conspiração silenciosa da indolência ativa, para falar da solidão de quem ousa marcar posição. Não é exagerado então imaginar, conforme essa dramática da existência, que Nietzsche poderia muito bem dançar l'après midi d'un faune à maneira de Nijinski. Lima Barreto, que aliás leu Nietzsche no mesmo livro resenhado por Veríssimo, as Pages choisies por Henri Albert, toca neste ponto quando anota, em seu Diário intimo, um pensamento de Balzac, em Peau de chagrin, "muito semelhante a um de Nietzsche: 'L'homme est un bouffon que danse sur des précipices"' (Lima Barreto 54). A dança sobre o abismo intitulam-se, precisamente, as memórias de Gilberto Amado, memórias de um tempo em que um adolescente, Murilo Mendes, sente-se compelido à literatura por ter visto Nijinski dançar ou até mesmo por ter desconfiado que Nijinski era dançado pela dança.

É mais ou menos compreensível que os modernistas olhem, com certa suspicácia, o decadentismo de Nietzsche, esse Super-Hitler, como diz Oswald de Andrade. Sendo 
híbrido e bárbaro, é parvenu; é um "prurido de aparecer (que) se manifesta na ostentação de cultura, na declamação em alta voz, na intenção de refazer, de renovar" que no fundo, como argumenta Graça Aranha em A estética da vida, nada mais é do que tentar sobrepujar a França esgotada. Como "é preciso criar o novo (os alemães) se apoderaram do que a França produzia de mais moderno para se mostrarem adiantados e progressistas", disto derivando "sempre o bárbaro, o grosseiro que a civilização deslumbra e que ao menor verniz de cultura se julga ultra-civilizado; e daí um paroxismo de expressão, um prurido de novidade e uma necessidade de brilhar" (Aranha 215-17). ${ }^{1}$

Hoje, que não podemos ter em relação à capital do século XIX o mesmo fascínio dos modernistas e que inclusive concebemos o esclarecimento como algo mais do que uma ditadura da luze da transparência, isto é, como um auto-esclarecimento dramático, feito de adesão à existência e desilusão da experiência, ou, em suma, como o revezamento inevitável de enigma e transparência, hoje, pois, tendemos a interpretar e avaliar o bizarro sob outra perspectiva. Uma perspectiva genérica, senão genética. Sloterdijk vê, assim, na literatura do século XX, a realização mais acabada do espírito centáurico adiantado por Nietzsche. Em Humano, demasiado humano, como se recordará, seu autor argumenta que uma civilização superior deverá dar um duplo cérebro ao homem, um para ser sensível à ciência, outro para obedecer à não-ciência. A literatura seria, então, essa língua franca destinada aos espíritos livres, poliglotas, de Hoffmann a Freud, de Kierkegaard a Adorno, de Novalis a Valéry, de Brecht a Foucault, de Benjamin a Barthes e, para não citar apenas os exemplos do próprio Sloterdijk, digamos, de Xul Solar a Perlongher. Ora, mais apropriado talvez do que falar de literatura seria falar de ficção, isto é, aquele fragmento textual trabalhado pela

\footnotetext{
'Elysio de Carvalho, que traça um retrato explícito de Graça Aranha em Príncipes del espiritu americano, ficcionaliza o escritor em Five o'clock tea: "O mestre muito amado me promettera, para delicia de meu espirito, uma hora encantadora na sua bella residencia em Petropolis, onde curava então minha neurasthenia. O ambiente era impregnado de suaves perfumes, e quando uma leve brisa de verão soprava entre as arvores do jardim, entrava pelas vastas janellas abertas para um lindo céo puramente azul, em cujo fundo sereno se desenhava tão nitidamente a accidentação das montanhas proximas, um odor subtil de lilazes, magnolias e jasmins. A paysagem, calma e luminosa, era digna dessa morada olympica onde reinavam a doce paz espiritual das cousas sagradas pela divindade do entendimento, a visão de incomparaveis firmamentos, magicas auroras e poentes prodigiosos de uma natureza magnifica e a contemplação de marmores divinos de belleza e bronzes orgulhosos de eternidade. Toda a tarde conversámos no seu gabinete de estudo, um pequeno salão de estylo grego, guarnecido de nobres tapeçarias e ricos moveis, povoado de obras d'arte, estatuas e quadros, tendo no fundo, dominando toda a sala, um admiravel busto de Frederico Nietzsche e um pouco mais longe uma soberba copia da Gioconda de Da Vinci. Attento, maravilhado como em presença de um prodigio, fiquei a escutar durante algumas horas o philosopho insigne que, grave e ardente, solemne qual um visionario, exprimia com palavras puras idéas luminosas. Fallou da esthetica da vida e do sentimento tragico, tratou de Goethe e da cultura moderna, fez a apologia de Shelley e recitou versos de Alberto de Oliveira, narrou suas peregrinações estheticas á Roma, á Florença e á Veneza, á Londres e á Paris, em summa, tratou da vida e do mundo, com uma tal intensidade de emoção que a sua palavra embebedava como um perfume oriental e ás vezes produzia o extase (115-6).
} 
teoria. A ficção é uma instância da experiência, entendendo experiência não como acúmulo de informações empíricas mas como elaboração de um significante que se nos impõe como instância crítico-prática da memória.

Se vemos em Nietzsche o criador de uma literatura centáurica que seria expressão de um materialismo dramático e se vemos, nessa forma emergente, a marca da ficção - ficção teórica, ficção crítica- contemporânea, não há como não concluir que esses conceitos consolidam a continuidade entre o primeiro Nietzsche, decadentista e hipersensível, e o segundo Nietzsche, impugnador da Teoria Crítica. Poderíamos dizer, em resumo, que a passagem de um a outro Nietzsche é a passagem de Nietzsche a Borges. Outros poderiam traçar essa tangente entre Nietzsche e Benjamin ou mesmo entre Nietzsche e Adorno. Prefiro, porém, concentrar-me em Borges porque, além do mais, essa peculiar recepção de Nietzsche firma a ponte entre o segundo e o terceiro momentos nietzscheanos entre nós, na América Latina.

A marca de Nietzsche é relevante para entender o mecanismo das fiç̧ões borgeanas. A noção de releitura do passado; a interpretação como gesto dúplice de inventar conhecendo e conhecer inventando; a reivindicação do fragmento por seu conteúdo de verdade suficiente; a função do autor como filósofo-artista, em busca, teatral, de uma filosofia do estilo (cínica, sígnica), tudo, enfim, o que lemos em Nietzsche retomamos em Borges, disseminado, disfarçado. Poder-se-ia mesmo submeter essa manifestação recorrente a um ensaio de significação corrente o que, não nego, implica a maior heresia em relação à aberta disponibilidade desses fragmentos. Porém, dado que toda ordem é uma peculiar versão do caos, poderíamos ensaiar uma organização tão caprichosa como outra qualquer e que consistiria em articular esses fragmentos de Borges, onde se lê a marca de Nietzsche, como sequência cronológica, admitindo, de antemão, que a ilusão de continuidade é um dos efeitos de toda ficção ou interpretação. As vantagens desse método ficcional se verão logo a seguir.

Otto Dietrich zur Linde, o narrador de "Deutsches Requiem" (1946) declara ter conhecido a obra nietzscheana em 1927 mas, em Borges a primeira marca resgatável de Nietzsche ocorre, de fato, numa observação de 1925, em que o escritor alemão é usado para ilustrar uma posição do discurso - a da intensidade ou desarmonia - em oposição à extensão harmoniosa de Goethe e em sintonia, aliás, com uma outra atitude intensiva e não harmônica, contemporânea e admirada, no primeiro Borges. Refiro-me ao expressionismo. Mas, pouco depois, lemos em El idioma de los argentinos (1928), uma passagem esclarecedora. Argumenta o escritor que a verdade literária é uma ficção, conceito, como sabemos, central no debate estético proposto por Borges. Diz:

Nietzsche compara a lua a um gato (a um indivíduo macho, Kater) e a um monje. Essa virilidade (varonia) de suas metáforas, árdua em Buenos Aires, é evidente na Alemanha: os alemães dizem o lua (El idioma 159).

Nietzsche aparece aqui para validar uma dupla construção identitária como construção ficcional. Porque se, em El idioma de los argentinos, a preocupação 
nacional é determinante e o desvio de Nietzsche confirma a diferença do idioma dos alemães, não é menos importante destacar que a arbitrariedade cultural nacional se extende, problematicamente, à representação de gênero. Nietzsche surge, então, para desfeminizar, dessublimizar, o emblema característico dos românticos, a lua, e mostrar assim a labilidade de toda representação.

Essa tensão de linguagem, feita ao mesmo tempo de amnese e anamnese, retorna em Historia de la eternidad (1936). Com efeito, em “A doutrina dos ciclos" o autor fixa seu dissenso em relação a Nietzsche no campo da sintaxe:

Nietzsche sabia que o Eterno Retorno é das fabulas ou medos ou divertimentos que recorrem eternamente mas sabia também que a mais eficaz das pessoas gramaticais é a primeira (Obras completas 388)

argumento que serve, em sua primeira parte, para anular a substância do eu, mera reedição de outras subjetividades pretéritas, nonada ou nadería; mas, a seguir, e aí entra outra concepção de história, ele funciona para afirmar não só que o eu é viável como também profético. Se o primeiro argumento desfaz a própria existência de Nietzsche, embora adira superficialmente a sua argumentação, o segundo, de modo paradoxal, ao se distanciar de Nietzsche, o reconfirma. Problematicamente Nietzsche é Byron ou Baudelaire, Whitman ou esse outro de Valéry que é Monsieur Teste. Pouco mais tarde, em 1941, Borges publica um ensaio, "Tres formas do eterno regresso" (La Nación, 14 dez) que irá logo se incorporar à Historia de la eternidad com o título "El tiempo circular". Arrola aí essa enumeração parcial de precussores: $039^{\circ}$. parágrafo do Timeu de Platão, argumento astrológico retomado por sir Thomas Browne na Religio Medici (1643); o argumento do atomismo, que sendo de Nietzsche também o fora de Le Bon e de Blanqui, o communard. Mas também o argumento de o passado ou o futuro serem incognoscíveis e inapropriáveis, argumento de Hesíodo, Heráclito, Bacon. Essas interpretações servem a Borges para avaliar a posição do presente (1941) diante da questão da temporalidade e propor não a euforia profética inaugural mas a constatação melancólica de uma modernidade tardia (não central ou periférica):

Em tempos de auge, a conjectura de que a existência do homem é uma quantidade constante, invariável, parece entristecer ou irritar; em tempos que declinam (como estes) é a promessa de que nenhum opróbrio, nenhuma calamidade, nenhum Hitler poderá nos empobrecer. ${ }^{2}$

Em outro ensaio inédito dessa fase, "Ensayo de imparcialidad"(Sur, 61, out 1939), é Nietzsche quem, sintomaticamente, aparece identificado com o ditador. O argumento é o de que, em um momento de polarização como o da guerra, criticar os excessos do liberalismo ("as piratarias inglesas") é aprovar "com fervor que Adolf Hitler obre a la Zarathustra, para além do bem e do mal", o que é ruim para nós, menos pelo "imaginário

${ }^{2}$ Na versão em livro (Obras completas 396) Borges substitui Hitler por "nenhum ditador". 
perigo de uma aventura colonial sul-americana" do que pelo inexorável fracasso que acarretariam "os imitadores autóctones, os Uebermenschen caseiros". Diríamos que, quando Nietzsche cai na história, é difícil mantê-lo no plano de uma simples soberania artística individual, equidistante de eternidade e contingência; é portanto ousado, quando não inviável, recortá-lo (como toda leitura, aliás) do constante exercício de apokatástase. Se a história nos condena à contingência, a estética, entretanto, abre-nos à pluralidade de tempos e espaços possíveis.

É sintomático, então, observar que estas notações se encadeiam ao texto chave do período, "Pierre Ménard, autor do Quixote" (1939). Aliás, uma das leitoras de Ménard, a baronesa de Barcourt, vê, nesses pastiches, a influência de Nietzsche; e, além do mais, em outro relato dessa época, o embate antipositivista do zoólogo Philip Henry Gosse também parece apoiado na teoria dos ciclos do filósofo alemão. Poderíamos, quiçá, abusar das recorrências e atribuir a esta baronesa de Barcourt a autoria de outro texto, "Alguns pareceres de Nietzsche"(La Nación, 11.2.1940), onde o Zarathustra se define, à maneira do Quixote de Ménard, como "um pastiche judeu-alemão", portanto, como texto dúplice, senão dúbio, e como "um prophetic book ainda mais artificial e muito menos apaixonado do que o de Blake".

Observe-se, entretanto, que reaparece nestes casos, a estratégia desconstrutiva e desestabilizadora que observáramos em "A doutrina dos ciclos". Ao analisar o hibridismo dionisíaco do judeu-alemão, Borges argumenta que o nacionalismo judeu "é o mais exorbitante de todos, pois a impossibilidade de invocar um país, uma ordem, uma bandeira, impõe um cesarismo intelectual que costuma exceder a verdade. $O$ nazista nega a participação do judeu na vida alemã; o judeu, com injustiça igual, finge que a cultura da Alemanha é cultura judia". Interessante argumento porque se Nietzsche (como Ménard) poderiam ser emblemáticos de um espaço globalizado e um tempo imaterializado, espaço e tempo, em suma, pós modernos, Borges não deixa de observar que esse nomadismo (judeu) não é menos inquietante do que a territorialização modernista porque, por trás da tolerância, subjaz a idéia repugnante de tolerar toda e qualquer atitude, até mesmo a intolerante, onde Nietzsche (o judeu) se converte em Hitler (o Kaiser, o cesarista, o alemão). Talvez esta percepção desenvolva em Borges a noção de que, na modernidade, toda representação (a identidade aí incluída) é aporética. Entre 1941 e 1943, ele trabalha, com efeito, numa série de textos que tentam explorar as virtualidades dessa sobredeterminação do ético e do estético. Eles precisam ser lidos em dois níveis. No explícito ou visível, eles defendem a autonomia estética; no implícito ou invisível, discutem a referencialidade histórica. Essa cisão visível/ invisível, como é óbvio, remete à estrutura palimpsestuosa das leituras de Ménard. Ora, creio que cabe aplicar a esses textos os recursos enviesados do anacronismo deliberado e da atribuição errônea. Vejamos de que modo.

"A biblioteca total"3 concretiza o horror -obliterar o dia, disseminar o caos- na impossibilidade de optar. A biblioteca guarda tudo e tudo confirma, nega, ou confunde

\footnotetext{
${ }^{3}$ Sur, 59 (Buenos Aires, ago. 1939: 13-16).
} 
ao mesmo tempo. A biblioteca é "um deus que delira", afirmação paradoxal em que, melancolicamente, insinua-se que deus perdeu a razão, isto é, que está "morto", mas, de outro lado, e em forma auspiciosa, constata-se que uma das faculdades divinas é excessivamente humana: ser irracional. No texto, Borges hierarquiza, marca, realiza opções "racionais". Nos diz que a ficção da biblioteca total "é um avatar tipográfico dessa doutrina do Eterno Retorno que concebida pelos estoicos ou por Blanqui, pelos pitagóricos ou por Nietzsche, regressa eternamente". A rigor, o narrador de "A biblioteca total" é um pasticheiro de textos futuros (o dos pareceres em Nietzsche, de 40 , ou o das três formas do eterno regresso, de 41), alguém que nos persuade que non in tempore sed cum tempore incepit creatio. Esse narrador, em suma, é um Pierre Ménard da Historia de la eternidad. E aí nos encontramos com a disjuntiva do trabalho ficcional: ora o narrador assume a ilusão do total que subjaz a qualquer uso do efeito do real, operação em que o narrador fica reduzido a um memorioso Funes, ora o narrador assume a amnésia, quando não a anistia, em relação ao passado e delira todas as combinações cabíveis. Se, na primeira combinação, seu retrato se confunde com o desvario irracional, no segundo, porém, ele assume a feição de uma hipertextualização pós-histórica. É assim, creio, que devemos ler um texto geminado a esse, "A biblioteca de Babel" (1941). Se a memória de Funes dita os pormenores da versão de 1939, a desmemória híbrida deste novo relato, autêntica obra pierremenardesca, apaga todos os traços e, mesmo afirmando que a biblioteca (como figuração do universo) éilimitada e periódica, não há, no conto da organização babélica, o nome de um único autor delimitando propriedades. Como no raiar de um dia apocalíptico em que Guernica impera, o narrador se consola com a cíclica repetição dos volumes infinitos e inacabados raciocinando que sua "solidão se alegra com essa elegante esperança".

Paralelamente a "A biblioteca de Babel", Borges resenha um livro de Gerald Heard, Pain, Sex and Time, e nesse artigo volta ao Zarathustra para qualificá-lo, como o fizera em "Alguns pareceres ...", de "desairosa (desdenhosa, desairada) paródia de todos os Sacred Books of the East" mas para acrescentar, ainda, outra marca relevante: a de que a teoria cíclica da história só podia ter sido concebida por um "acadêmico inepto coibido pelo culto supersticioso (...) dos clássicos" (Obras completas 277-9). Glosa aí uma opinião pioneira de Bernard Shaw de quem dirá, em artigo de 1957, ser mestre de Nietzsche. Mas, ao mesmo tempo, avança um argumento todo seu que será decisivo em textos como "O escritor argentino e a tradição" (1953) ou "Kafka e seus precursores" (1951), embora já perceptível em outro esparso que, coincidentemente, é de 1941: "Sobre os clássicos" ${ }^{4}$ A tarefa de fixar um texto canônico é definida, então, com palavras de Nietzsche, como um "problema fortuito e temporal e desnecessário e efêmero", alimentando, novamente, o paradoxo: "não interessa o mérito essencial das obras canonizadas; interessam a nobreza e o número de problemas que elas suscitam".

Recorre, pois, a um argumento estético (a canonização literária) para combater valores éticos (a representação da identidade nacional), e o exemplo mais uma vez

4 "Sobre los clásicos". Sur, 85 (Buenos Aires, out. 1941: 7-12). 
redunda no Quixote. A "deificação" desse texto produziu, na literatura hispânica, efeitos melancólicos: se um shakespereano "é sempre um ser civilizado", um cervantista, entretanto, costuma ser um mero gramático. O mais grave, porém, é que a lógica do nacionalismo latino-americano aguçou o efeito, produzindo "uma espécie ainda mais pobre de cervantistas", os especialistas em literatura gauchesca. Conclui-se, portanto, que como não possuimos tradição definida nem livro digno de ser símbolo perdurável, "essa aparente privação é antes um alívio, uma liberdade que não devemos nos apressar a corrigir" porque "gozamos de uma tradição potencial que é todo o passado". Afirma, em consequência, que a lógica do trabalho de interpretação, a apokatástase históricoliterária, impõe uma causalidade não apenas sobredeterminada, porém, retrospectiva: "basta que um fato aconteça para que seja necessário, fatal". Ora, o que é necessário e fatal senão um antídoto contra o livro "deificado"? E quem poderia propor uma escritura que fosse anti-modelo do mundo? Apenas "um deus que delira", alternativamente Zarathustra, o ditador, Pierre Ménard, "a teratológica Trindade: o Pai, o Filho e o Espectro insolúvel, articulados em um único organismo", a biblioteca total, le livre, o cânone.

Com efeito, só um deus dionisíaco e delirante teria condições de corrigir a história. Como Borges acredita que "os deuses negaram aos alemães a beleza espontânea", Nietzsche, esse Ménard anticanônico, teria escrito $A$ origem da tragédia como história de uma infâmia, a de proclamar Unser Shakespeare, nosso Shakespeare, donde Nietzsche seria autor de "O escritor alemão e a tradição", um típico "Ménard", como lemos em uma resenha do livro de Gilbert Waterhouse, $A$ Short History of German Literature, redigida em $1943 .^{5}$

Mas, de todas essas ocorrências, a mais ilustrativa é também a mais circunstancial. Em 1944, comemorando precisamente o centenário do autor, Borges se dedica a desvendar "El propósito de Zarathustra" em ensaio para La Nación meticulosamente retirado de sua obra édita, ${ }^{6}$ talvez por achá-lo datado, no sentido de feito sob encomenda, talvez por nele se encerrar a chave que identifica Nietzsche/Zarathustra com Borges/Pierre Ménard ou ainda por associar a doutrina dos ciclos com o conceito de ficção praticada por Borges.

"Ninguém pode deixar de observar - nos confessa no início de sua argumentação- que o mais ilustre dos livros de Nietzsche (...) é uma imitação formal dos textos canônicos orientais". E arremata a aporia ponderando que, coincidentemente, ninguém conseguiu esgotar o sentido desse traço formal. Para ilustrar esta conclusão, enumera, em sequência, os intérpretes de Nietzsche: Alexander Tille vê afinidades entre Zarathustra e o cânone budista, os Evangelhos, o Divã oriental-ocidental de Goethe, a sabedoria brahmânica de Rückert e as epopéias germânicas de Felix Dahn. Já a irmã do filósofo, Elizabeth Förster-Nietzsche, vê o Zarathustra como "o livro mais íntimo e pessoal" do autor, contendo as amizades, os ideais, os êxtases e os desenganos do

\footnotetext{
${ }^{5}$ Obras completas (280).

6 "El propósito de Zarathustra". La Nación. Buenos Aires, 15 out 1944.
} 
filósofo. Até o próprio Nietzsche é citado como intérprete de si mesmo, ao definir essa sua obra em termos de composição musical. Nada disso, entretanto, satisfaz plenamente a Borges. Mais ainda: nem mesmo Zarathustra a seu ver é um livro satisfatório por "uma sintaxe de feições arcaicas, e um vocabulário neológico, a máxima energia e a máxima imprecisão", a ambigüidade de sentido e a pompa da diç̧ão que o tornam um "livro para todos e para ninguém".

Detem-se, então, a examinar os dois aspectos dessa obra, a doutrina do superhomem e a teoria do retorno. Considera a primeira equívoca ao passo que vê a segunda como problemática. Há aqui uma inequívoca autobiografia já que, se para Nietzsche, "a história universal é interminável e periódica", ilimitada e periódica era também para seu autor “A biblioteca de Babel”. Daí que seja necessário, ao ler Nietzsche, uma rasura que reponha o nome do Borges como sujeito do período. Então, se "Nietzsche pondera a intolerável novidade dessa conjectura" (de o universo ser cíclico e periódico) cabe pensar que para Borges a idéia de um Biblioteca Total ia além de uma simples novidade intolerável: ela configura a intolerabilidade da pura novidade ou, em outras palavras, descentra o moderno em uma instância de identificação (o auspício do novo) e outra de desilusão (a exaustão do déjà vu). Arrola, então, nosso autor esse tédio ou acúmulo de versões que redundam o retorno dos ciclos: é Plutarco, no primeiro século da era; é Orígenes, a começos do III; é Santo Agostinho, no século V; é Hume, a meados do XVIII. Como interpretar a reincidência? Confusão entre lembrança e inspiração, quando não entre memória e transcrição, dizem os detratores. Dentre os defensores, alguns comentaristas, "para absolvê-lo da imputação de plágio, atribuem-lhe surpreendente ignorância", ao passo que outros interpretam o Eterno Retorno como um mero adorno retórico. A posição de Borges é singular. Crê que toda essa controvérsia se desfaz se consideramos o esforço de Nietzsche no sentido de escrever um livro sagrado ou seja que o debate erra na classificação ou rotulação da obra, em seu aspecto genérico, e não em questões materiais: "o tom inapelável, apodíctico; os anátemas infundados; as ênfases, a ambigüidade, a preocupação moral (...) as repetições, a sintaxe arcaica; a deliberada omissão de referência a outros livros; as soluções de continuidade; a soberba, a monotonia; as metáforas; a pompa verbal", tudo isso, enfim, demonstra que Zarathustra não é nenhuma das duas coisas a que costumamos associá-lo. Nem livro dialético, nem poema, o propósito de Nietzsche foi "a composição de um livro sagrado". Zarathustra pratica a literatura centáurica: discute as representações enquanto sintaxe. Como se vê, reatamos os argumentos apresentados em 1925-28. A ficção retorna, o sujeito é uma ficção, porém, a ficção difere.

Mallarmé, que perseguia o livro absoluto, escreve em Igitur que o acaso contém o absurdo e implica o capricho mas sempre em estado latente, o que os impede de existirem nos fatos e lhes permite ser apenas no infinito. Em outras palavras, ao politizar o acontecimento a interpretação, que é sempre lance do fortuito, coloca o absurdo ou o inadmissível em latência de procedimento e esse mecanismo torna a avaliação ética e a ação política viáveis e possíveis. 
Em "Sobre os clássicos”, Borges deplorava "a canonização irrevogável do D. Quixote" e abominava os comentaristas, aos quais "não lhes interessa o importante: a ética do poema". Vale dizer que sua estratégia é propor uma canonização revogável, exatamente nos termos éticos de Nietzsche e com o alcance estético de Ménard. Essa seria a dimensão política do texto absoluto na biblioteca total: produzir o objet dard.

Se é lícito pensar que "gozamos de uma tradição potencial que é todo o passado" ("Sobre os clássicos") e se cabe afirmar que "nossa tradição é toda a cultura universal" ("O escritor argentino e a tradição"), é indispensável discriminar a ética individual (de Nietzsche ou de Borges) da "nenhuma ética do nazismo". Caso contrário, estaremos alimentando "outra guerra, em que desapareçam todos os livros do orbe ocidental, salvo o enigmático Zarathustra, que fatalmente, quem sabe em que nações e em que dialeto, ascenderá o livro sagrado", mercê de sua "ética da felicidade valorosa".

Caberia, em consequência, pensar essa ética como a contraface de uma estética do ínfimo ou até mesmo do infame. Afinal, não se afirma uma escritura infinita ou abjeta sem uma ética discursiva, homóloga e específica, uma ética que, de um lado, suspenda a decisão que tange à ciência, mas também à fábula, isto é, a decisão entre verdade e falsidade, mas que, de outro lado, admita instalar-se, no plano da não verdade, como artifício deliberado capaz de produzir efeitos perceptíveis de verdade. A ética da felicidade valorosa e a estética do menor conformam assim o nosso materialismo dramático contemporâneo, terceiro momento de Nietzsche na literatura.

Murilo Mendes, a quem há pouco vimos motivado pelo espírito que dança, mesmo reprovando em Nietzsche o culto da força ou do mandarinato ou talvez por isso mesmo, por poder reunir no homem o passivo e o ativo, a criatura e o criador, propôs-se, em relação ao filósofo, a

[r]enovar sua didascália sobre o espírito grego como ponto de partida da cultura e sobre o espírito israelita como organizador da ação. Desnazificar Nietzsche. Desprussianizá-lo (Mendes 1210).

Ser nietzscheano contra Nietzsche, extirpar a função maior de seu discurso implica, em contrapartida, desenvolver uma peculiar função oblíqua, a de imaginar Nietzsche como um transcristão, alguém que mostrasse a cada um que "deveria explorar a parte de Dionísio que lhe toca" para melhor interpretar a disciplina do drama.

Ora, a ficção já se adiantara na construção de um imaginário centáurico. Não custa lembrar que o texto de Guimarães Rosa foi cedo interpretado como transrealista por unir "o espírito telúrico e o espírito oceânico, (...) duas faces de todo o continentalismo literário americano" (Coutinho 142-3). Tristão de Athayde julgava encontrar nesse universalismo a chave católica do escritor assim como, mais tarde, em perspectiva dialética, Antonio Candido interpretaria o materialismo de Guimarães Rosa como super-regionalista ou transvanguardista. A posição de Alceu Amoroso Lima conflui, como se vê, com a leitura desse outro católico heterodoxo que é Murilo, donde poderíamos pensar em Augusto Matraga como um peculiar super-homem brasileiro, 
misto de herói transcultural e centáurico. Um portador transcristão, com efeito, é nosso Matraga. Nem Augusto Esteves, filho do Coronel, nem Nhô Augusto, o simples homem, "Matraga não é Matraga, não é nada". Matraga é a ficção como terceira margem da fabulação, prévia e posterior à literatura; ele é a violência depurada de história porém santificada, como autocriação do sujeito, numa "espécie nova e mui serena de alegria". Hélio Oiticica sintetiza: "Seja marginal, seja herói”. Caetano redunda "alegria, alegria". Ainda transcristão é Mineirinho. Aliás, Matraga é Mineirinho, alguém que nos detona a passagem do sonso essencial ao doido libertário. Porque procura entender e, no entanto, fica mudo, o doido desorganiza. Ele compreende que é perigoso compreender e por isso exige o incompreensível, uma justiça ainda mais doida, "uma que levasse em conta que todos temos que falar por um homem que se desesperou porque neste a fala humana já falhou, ele já é tão mudo que só o bruto grito desarticulado serve de sinalização" (Lispector 256).

Como uma sorte de baronesa de Barcourt rediviva, Clarice Lispector constrói em "Mineirinho" uma réplica da biblioteca de Babel que deslê os prophetic books do passado. Assim, com Guimarães Rosa ou com Clarice Lispector, a ficção ambiciona o bruto grito desarticulado, a linguagem despida de discurso, a musa moderna da impotência, como queria Mallarmé, que descobrisse "les jouissances d'une âme purement passive que n'est pas femme encore, et qui demain peut-être será bête".

Nessas ficções transcristãs, contrariamente aos relatos pagãos que identificam destruição com injustiça, temos a dramatização do conflito bíblico, em que a destruição realiza a autêntica justiça. Como observa Deleuze, a modernidade do Apocalipse não está nas catástrofes anunciadas mas na auto-glorificação programada e na instauração demencial de um poder absoluto, o planejamento burocrático-industrial do Estado onipresente. Para o pensamento 68, o Apocalipse não é exatamente o campo de concentração adorniano mas a segurança do Estado; não é bem a disciplina foucaultiana mas o controle como biopolítica.

Em O discípulo de Emaús (1945), Murilo Mendes pondera que a vida não é apenas um espaço de observação e experiência técnicas, ela é também um poderoso campo de improvisações que nos levam a exigir a síntese da loucura. Vinte anos mais tarde, o poeta de Texto délfico encerra seu retrato-relâmpago dedicado a Nietzsche com outra defesa das sensações antipráticas e das inesperadas metamorfoses; trata-se de uma peculiar leitura da cifra enquanto enigma e do tempo descontínuo como história liberta que poderia, sem esforço, ser assinada por Benjamin ou Foucault mas que, antes deles, foi escrita pelo próprio Nietzsche:

A palavra do passado é sempre palavra de oráculo: só a compreendereis se fordes os construtores do futuro e os visionários do presente.

Enquanto para os primeiros nietzscheanos, o eterno retorno era a forma de uma consciência pré-histórica do mundo, sem reflexão, por exemplo, sobre o vínculo entre Zarathustra, César e o imperialismo, graças ao conceito de ficção como literatura 
centáurica, entretanto, a leitura contemporânea de Nietzsche não só reflete sobre as relações entre saber e poder mas se concebe a si própria, atravessada por essas linhas, como consciência pós-histórica da modernidade. Não em vão é a partir de Nietzsche que Walter Benjamin elaborará seu conceito de dialética em repouso como cabeça de Medusa, em que todos os traços do mundo se petrificaram em agonia glacial. Para os contemporâneos, entretanto, a tradição adquire, enfim, a feição de uma fantasmagoria em que, a pré-história, entendida como Urgeschichte, se nos apresenta em roupagens ultra-modernas provando a concomitância apocalíptica de próprios e estranhos (Benjamin 141).

\section{Obras citadas}

Aranha, Graça. "Nietzsche e sua Alemanha". A estética da vida. Rio de Janeiro: Garnier, 1921.

Athayde, Tristão de. "O transrealismo de G. R.”. Jornal do Brasil (Rio de Janeiro, 30.8.1963). Guimarães Rosa. Ed. de Eduardo Coutinho. Rio de Janeiro: Civilização Brasileira/INL, 1983.

Benjamin, Walter. Paris, Capitale du XIXe siècle. Paris: Cerf., 1993.

Borges, Jorge Luis. Obras completas. Buenos Aires: Emecé, 1974.

El idioma de los argentinos. Buenos Aires: Gleizer, 1928.

Carvalho, Elysio de. Five o'clock tea. Rio de Janeiro: Garnier, 1909.

Coutinho, Eduardo. Guimarães Rosa. Rio de Janeiro: Civilização Brasileira/INL, 1983.

Deleuze, Gilles. Critique et clinique. Paris: Minuit, 1993.

Descombes, Vincent. "O momento francês de Nietzsche". Boyer, Alain et al., Porque não somos nietzscheanos. Trad. de R. Leal Ferreira. São Paulo: Ensaio, 1993. Lima Barreto, A. H. de. Diário íntimo. São Paulo: Mérito, 1953.

Lima, Alceu Amoroso. Estudos. 2. série. Rio de Janeiro: Terra de Sol, 1928. Lispector, Clarice. A legião estrangeira. Rio de Janeiro: Editora do Autor, 1964. Mendes, Murilo. Poesia completa e prosa. Rio de Janeiro: Nova Aguilar, 1994. Ribeiro, João. O fabordão. Pref. A. Meyer. Rio de Janeiro: São José, 1964.

Rio, João do (pseud. Paulo Barreto). No tempo de Wenceslau. Rio de Janeiro: Villas Boas \& Co., 1917.

Crônicas e frases de Godofredo de Alencar. Rio de Janeiro: Villas Boas \& Co., 1916.

Sloterdijk, Peter. Le Penseur sur scène. Le materialisme de Nietzsche. Trad. de A. Hildebrand. Paris: Ch. Bourgois, 1990.

Veríssimo, José. "Retórica de Nietzsche". Homens e cousas estrangeiras. $3^{\mathrm{a}}$ série, 1905-1908. Rio de Janeiro: Garnier, 1910. 